\title{
Article \\ Bioactive Composition and Nutritional Profile of Microgreens Cultivated in Thailand
}

\author{
Laddawan Kowitcharoen $^{1}$, Surisa Phornvillay ${ }^{1}$, Pornpan Lekkham ${ }^{1}$, Nutthachai Pongprasert ${ }^{1,2}$ (D) \\ and Varit Srilaong $1,2, *$ (D)
}

1 Division of Postharvest Technology, School of Bioresources and Technology, King Mongkut's University of Technology Thonburi, 49 Tientalay 25, Thakam, Bangkhuntien, Bangkok 10150, Thailand; lekk_6@hotmail.com (L.K.); surisaphornvillay@gmail.com (S.P.); mintkmutt93@gmail.com (P.L.); nutthachai.pon@kmutt.ac.th (N.P.)

2 Postharvest Technology Innovation Center, Ministry of Higher Education, Science, Research and Innovation, Bangkok 10400, Thailand

* Correspondence: varit.sri@kmutt.ac.th; Tel.: +66-2-470-7726

Citation: Kowitcharoen, L.;

Phornvillay, S.; Lekkham, P.;

Pongprasert, N.; Srilaong, V. Bioactive Composition and Nutritional Profile of Microgreens Cultivated in Thailand. Appl. Sci. 2021, 11, 7981. https://doi.org/10.3390/app11177981

Academic Editors: Gang Ma, Masaya Kato and Pongphen Jitareerat

Received: 1 August 2021

Accepted: 27 August 2021

Published: 28 August 2021

Publisher's Note: MDPI stays neutral with regard to jurisdictional claims in published maps and institutional affiliations.

Copyright: (c) 2021 by the authors. Licensee MDPI, Basel, Switzerland. This article is an open access article distributed under the terms and conditions of the Creative Commons Attribution (CC BY) license (https:// creativecommons.org/licenses/by/ $4.0 /)$.

\begin{abstract}
Microgreens are young and tender leafy vegetables that have gained wider consumer acceptance. This is attributed to their low caloric composition and rich micronutrient and antioxidant composition. The present study investigated the bioactive composition and proximate analysis of fourteen microgreens belonging to Brassicaceae, Fabaceae, Pedaliaceae, Polygonaceae, Convolvu-

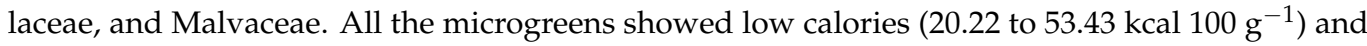

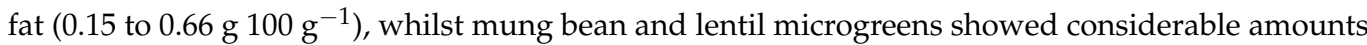

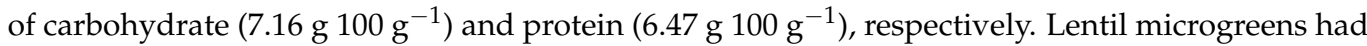
the highest total chlorophyll (112.62 mg $\left.100 \mathrm{~g}^{-1}\right)$ and carotenoid $\left(28.37 \mathrm{mg} 100 \mathrm{~g}^{-1}\right)$ contents, whilst buckwheat microgreens showed the highest total phenolic content (268.99 mg GAE $100 \mathrm{~g}^{-1}$ ) and DPPH• scavenging activity $\left(90.83 \mathrm{mM}\right.$ TEAC $\left.\mathrm{g}^{-1}\right)$. The lentil microgreens also presented high ascorbic acid content $\left(128.70 \mathrm{mg} 100 \mathrm{~g}^{-1}\right)$ along with broccoli, Chinese kale, purple radish, and red cabbage microgreens $\left(79.11,81.33,82.58\right.$, and $89.49 \mathrm{mg} 100 \mathrm{~g}^{-1}$, respectively). Anthocyanin content was only detected in purple radish $\left(0.148 \mathrm{mg} \mathrm{CGE} 100 \mathrm{~g}^{-1}\right)$ and red cabbage $\left(0.246 \mathrm{mg}^{\mathrm{m}}\right.$ CGE $\left.100 \mathrm{~g}^{-1}\right)$. The results provide basic information and highlight the benefits of utilizing genetic biodiversity to obtain microgreens with the desired nutrients and antioxidants.
\end{abstract}

Keywords: antioxidants; bioactive compounds; proximate composition; microgreens

\section{Introduction}

In recent years, the attention towards microgreens is increasing due to the rise in public awareness of healthy eating worldwide. Microgreens are tender immature greens produced from the seeds of vegetables, herbs, or grains, inclusive of the wild relatives [1]. Microgreens can be cultivated in loose and soilless germination media and harvested 7-21 days after germination (species-dependent) when the cotyledon leaves have fully developed and the first true leaves have emerged [2]. These miniature greens are valued as nutraceuticals and functional foods owing to their health-promoting and disease-preventing properties in addition to their nutritional value. For instance, broccoli sprouts and microgreens have higher contents of bioactive compounds and potential antioxidants and exhibit higher anti-inflammatory and anticancer activities compared to their corresponding adult plants [3,4]. Microgreens are low in energy but rich in nutrients, bioactive compounds, and antioxidants [5]. During seed germination, biochemical changes occur within the seed, causing the activation of various enzymes related to the degradation of macromolecules into smaller molecules that the body can absorb easily. The changes also include the synthesis of biochemical compounds that affect germination, thus causing the amount of nutrients such as vitamins and antioxidants to increase rapidly. These nutrients and antioxidants all are beneficial to the human body as they can be absorbed quickly [6]. 
Crops that are commonly used for microgreen production are mung beans, soybeans, broccoli, alfalfa, lentils, mustard, radishes, red clover, and sunflowers [7-9]. The bioactive values obtained from wheat, lentils, radishes, and sunflowers show the microgreens tend to be richer in saturated fatty acids such as palmitic acid than unsaturated fatty acids [7]. On the other hand, alfalfa microgreens have significantly higher amounts of unsaturated fatty acids such as oleic and linoleic acids than those of other plants. For radish sprouts, it was found that the content of glucosinolates increased after germination. Glucosinolates are beneficial to humans in cancer prevention [10].

The popularity of microgreens also comes from the attractiveness of their shapes, colors, crispy texture, and unique flavor to both children and adults. Some microgreens also have a strong aroma. Moreover, their short production cycle has attracted greenhouse growers and small-scale farmers, thus, generating income for the farmers. The farmers are able to produce multiple cycles of microgreens compared to mature vegetables. Although a wide variety of microgreens are currently being produced, scientific data on their basic nutritional information and functional food potential are not widely available [2]. Most of the information is from temperate regions with little representation for tropical microgreens. Therefore, the main objectives of this study were to investigate the bioactive compounds and proximate composition of microgreens of tropical and subtropical origins, including from the family Brassicaceae, Fabaceae, and others. This information would provide a database and scientific evidence that is useful to farmers and consumers, both local and international. Furthermore, the data produced could add value to agricultural products, expand export opportunities as well as reduce the import of health food supplements, which are expensive but very popular today.

\section{Materials and Methods}

\subsection{Plant Materials and Experimental Design}

In this study, 14 microgreens belonging to the family of Brassicaceae (broccoli, Chinese kale, purple radish, radish, rat-tailed radish, and red cabbage), Fabaceae (fenugreek, green pea, lentil, and mung bean), Pedaliaceae (black sesame), Polygonaceae (buckwheat), Convolvulaceae (morning glory), and Malvaceae (roselle) were selected. The scientific nomenclature of the selected microgreens is shown in Table 1. The experiment was conducted using a completely randomized design (CRD).

Table 1. Common names and scientific nomenclature of the studied microgreens.

\begin{tabular}{ccc}
\hline Common Name & Scientific Name & Family \\
\hline Broccoli & Brassica oleracea L.var. italica & Brassicaceae \\
Chinese kale & Brassica oleracea L.var. alboglabra & Brassicaceae \\
Purple radish & Raphanus sativus L. var. longipinnatus & Brassicaceae \\
Radish & Raphanus sativus L. & Brassicaceae \\
Rat-tailed radish & Raphanus caudatus L. var. caudatus Alef & Brassicaceae \\
Red cabbage & Brassica oleracea L.var. capitataf. rubra & Brassicaceae \\
Fenugreek & Trigonella foenum-graecum L. & Fabaceae \\
Green pea & Pisum sativum L. & Fabaceae \\
Lentil & Lens culinaris Medicus & Fabaceae \\
Mung bean & Vigna radiata (L.) R. Wilczek & Fabaceae \\
Black sesame & Sesamum indicum L. & Pedaliaceae \\
Buckwheat & Fagopyrum esculentum Moench & Polygonaceae \\
Morning glory & Ipomea reptans L. & Convolvulaceae \\
Red roselle & Hibiscus sabdariffa L. & Malvaceae \\
\hline
\end{tabular}

\subsection{Growth and Cultivation}

The seeds for the cultivation of these microgreens were rehydrated and sterilized prior to germination at $21 \pm 1{ }^{\circ} \mathrm{C}$. Subsequently, the germinated seeds were sown in a tray $(30 \mathrm{~cm} \times 60 \mathrm{~cm} \times 3 \mathrm{~cm})$ and grown until the cotyledons were fully developed with 1-2 real leaves under a controlled environment at $23 \pm 1{ }^{\circ} \mathrm{C}, 65 \pm 5 \%$ relative humidity, and 
800-1000 $\mathrm{mg} \mathrm{L}^{-1}$ carbon dioxide concentration. The cultivation details of the 14 studied microgreens are shown in Table 2 . The seeds mostly required $5-6 \mathrm{~h}$ of soaking. Imbibition is crucial before germination as water uptake triggers a progressive cellular process needed for germination. Additionally, the water softens the seed coat and eases radical protrusion [11] The seeds were surface-sterilized with commercial sodium hypochlorite $\left(200 \mathrm{mg} \mathrm{L}^{-1}\right)$ and left to germinate overnight at $24 \pm 1{ }^{\circ} \mathrm{C}$, following techniques practiced by local commercial farmers. All of these microgreens were grown using soilless culture, and the growing materials used are found in Table 2 . The germinated seeds were let to sprout in the dark until a hypocotyl length of 5-10 cm depending on the species. Hence the different required periods of sprouting in the dark. After that, the microgreens were exposed to white fluorescent lights and harvested after the first true leave emerged, at varying durations depending on the species (Table 2). The microgreens were harvested from duplicate trays with scissors and used for proximate and bioactive compounds analyses.

Table 2. Microgreen species, soaking time, germination time, growing material, and durations for sprouting in the dark, light exposure, and harvesting.

\begin{tabular}{|c|c|c|c|c|c|c|}
\hline Microgreens & $\begin{array}{l}\text { Soaking } \\
\text { Time (h) }\end{array}$ & $\begin{array}{c}\text { Germination } \\
\text { Time }\end{array}$ & $\begin{array}{l}\text { Growing } \\
\text { Material }\end{array}$ & $\begin{array}{l}\text { Sprouting in the } \\
\text { Dark Time (Day) }\end{array}$ & $\begin{array}{c}\text { Light Exposure } \\
\text { Time (Day) }\end{array}$ & $\begin{array}{l}\text { Harvesting } \\
\text { Time (Day) }\end{array}$ \\
\hline \multicolumn{7}{|c|}{ Brassicaceae } \\
\hline Broccoli & $6 *$ & 1 night & Kinocloth $^{\circledR}$ & 5 & 4 & 9 \\
\hline Chinese kale & $6^{*}$ & 1 night & Sponge & 3 & 4 & 7 \\
\hline Purple radish & $6 *$ & 1 night & Sponge & 4 & 3 & 7 \\
\hline Radish & $6^{*}$ & 1 night & Sponge & 4 & 3 & 7 \\
\hline Rat-tailed radish & $6^{* *}$ & 1 night & Sponge & 4 & 6 & 10 \\
\hline Red cabbage & $6^{* *}$ & 1 night & Kinocloth $^{\circledR}$ & 5 & 5 & 10 \\
\hline \multicolumn{7}{|c|}{ Fabaceae } \\
\hline Fenugreek & $6 * *$ & 1 night & Sponge & 3 & 4 & 7 \\
\hline Green pea & $6^{* *}$ & 1 night & Peat Moss & 4 & 3 & 7 \\
\hline Lentil & $6^{* *}$ & 1 night & Sponge & 4 & 3 & 7 \\
\hline Mung bean & $12 *$ & 1 night & Sponge & 3 & 1 & 4 \\
\hline \multicolumn{7}{|c|}{ Others } \\
\hline Black sesame & $6 *$ & 1 night & Kinocloth $^{\circledR}$ & 3 & 5 & 8 \\
\hline Buck wheat & $6 *$ & 1 night & Sponge & 4 & 6 & 10 \\
\hline Morning glory & $6^{*}$ & 1 night & Sponge & 4 & 6 & 10 \\
\hline Red roselle & $6 *$ & 1 night & Sponge & 4 & 6 & 10 \\
\hline
\end{tabular}

* $200 \mathrm{mg} \mathrm{L}^{-1} \mathrm{NaOCl}$ was added in the 6th $\mathrm{h}$ of seed soaking; ${ }^{* *} 200 \mathrm{mg} \mathrm{L}^{-1} \mathrm{NaOCl}$ was added in the 5 th $\mathrm{h}$ of seed soaking.

\subsection{Proximate Analysis}

Ash, total protein, moisture, total fat, and total calories were determined according to methods of the Association of Official Analytical Chemists [12]. The total carbohydrate content was estimated by subtracting the other proximate parameters. All the parameters were assessed in duplicate.

\subsection{Phytochemical Analysis}

\subsubsection{Chlorophyll and Carotenoids}

Freshly chopped microgreens weighing $0.5 \mathrm{~g}$ were mixed with $20 \mathrm{~mL}$ of $\mathrm{N}, \mathrm{N}$ dimethylformamide and kept in the dark at $4{ }^{\circ} \mathrm{C}$ for $24 \mathrm{~h}$. After that, the mixture was filtered using Whatman filter paper No. 1, and the absorbance was read at 440,647, and $664 \mathrm{~nm}[13,14]$. Total chlorophyll was calculated as the sum of chlorophyll a (Chla) and chlorophyll b (Chlb) using the following formulas:

$$
\begin{aligned}
& \text { Chla }\left(\mathrm{mg} \mathrm{L}^{-1}\right)=12.64 \mathrm{OD}_{664}-2.99 \mathrm{OD}_{647} \\
& \text { Chlb }\left(\mathrm{mg} \mathrm{L}^{-1}\right)=-0.56 \mathrm{OD}_{664}+23.26 \mathrm{OD}_{647}
\end{aligned}
$$


The carotenoid content was calculated using the following formula:

$$
\frac{1000 \mathrm{OD}_{440}-0.89 \mathrm{Chla}-52.02 \mathrm{Chlb}}{245}
$$

The total chlorophyll and carotenoid contents were expressed as mg $100 \mathrm{~g}^{-1}$ of fresh weight.

\subsubsection{Anthocyanin}

The hypocotyls of purple radish and red cabbage weighing $1 \mathrm{~g}$ were sonicated with $10 \mathrm{~mL}$ of methanol containing $0.1 \%$ hydrochloric acid for $30 \mathrm{~min}$ at $40^{\circ} \mathrm{C}$. Subsequently, $0.5 \mathrm{~mL}$ of the obtained solution was mixed with two different buffer solutions $(2.5 \mathrm{~mL}$ of potassium chloride buffer ( $\mathrm{pH} 1.0$ ) and $2.5 \mathrm{~mL}$ sodium chloride buffer ( $\mathrm{pH} 4.5)$ ). The mixtures were then incubated at room temperature (RT) for $15 \mathrm{~min}$ prior to absorbance measurement by the scanning method $\lambda$, by reading the $\lambda$ vis-max and $\lambda 700$ values [15]. The anthocyanin concentration was calculated according to the following equation:

$$
\text { Anthocyanin pigment }=A \times \mathrm{MW} \times \mathrm{DF} \times 10^{3} / \varepsilon \times \mathrm{L}
$$

where, $A=(A \lambda$ vis-max $-A 700) \mathrm{pH} 1.0-(A \lambda$ vis-max $-A 700) \mathrm{pH} 4.5 ; \mathrm{MW}=$ molecular weight for cyanidin-3-glucoside $=449.2 \mathrm{~g} / \mathrm{mol}$; $\mathrm{DF}=$ dilution factor; $\varepsilon=26,900$ molar extinction coefficient; $\mathrm{L}=$ path length in $\mathrm{cm}$. The results were expressed as $\mathrm{mg}$ cyanidin-3glucoside equivalent (CGE) $100 \mathrm{~g}^{-1}$ of fresh weight.

\subsubsection{Total Phenolic Content}

The total phenolic content was determined according to the method by ethanolic extraction following Singleton and Rossi (1965) [16]. Briefly, $1 \mathrm{~g}$ of sample was homogenized with $15 \mathrm{~mL}$ of $80 \%$ ethanol and centrifuged at $12,000 \times \mathrm{g}$ for $20 \mathrm{~min}$. Then, $0.5 \mathrm{~mL}$ of filtrate was mixed with $2.5 \mathrm{~mL}$ of $0.2 \mathrm{~N}$ Folin-Ciocalteu reagent solution and $2 \mathrm{~mL}$ of $7.5 \%$ sodium carbonate. The mixture was incubated at RT for $90 \mathrm{~min}$, and absorbance was read at $760 \mathrm{~nm}$. The result was expressed as $\mathrm{mg}$ gallic acid equivalent (GAE) $100 \mathrm{~g}^{-1}$ of fresh weight.

\subsubsection{Total Antioxidant Activity}

The total antioxidant activity by 2,2-diphenyl-1-picrylhydrazyl (DPPH) radical scavenging activity was adapted from the method by Shimada et al. (1992) [17]. One gram of the samples was homogenized with $15 \mathrm{~mL}$ of $80 \%$ ethanol and centrifuged for $20 \mathrm{~min}$ at $12,000 \times g$. An aliquot of filtrate $(0.1 \mathrm{~mL})$ was then mixed with $2.9 \mathrm{~mL}$ of $0.1 \mathrm{mM} \mathrm{DPPH}$ working solution. The mixture was vortexed and incubated in the dark for $30 \mathrm{~min}$ at RT. The absorbance was read at $515 \mathrm{~nm}$, and the result was expressed as $\mathrm{mM}$ Trolox equivalent antioxidant capacity (TEAC) $\mathrm{g}^{-1}$ of fresh weight.

\subsubsection{Ascorbic Acid}

The ascorbic content was estimated based on Roe et al. (1948) [18]. A fresh sample weighing $2.5 \mathrm{~g}$ was homogenized with $10 \mathrm{~mL}$ of $5 \%$ metaphosphoric acid and filtered using Whatman No. 1 filter paper. The obtained filtrate of $0.4 \mathrm{~mL}$ was mixed with $0.2 \mathrm{~mL}$ of $0.02 \%$ 2,6-dichlorophenol-indophenol, $0.4 \mathrm{~mL}$ of $2 \%$ thiourea and $0.2 \mathrm{~mL}$ of $2 \%$ 2,4-DNP and incubated at $50{ }^{\circ} \mathrm{C}$ for $1 \mathrm{~h}$. Subsequently, $1 \mathrm{~mL}$ of $85 \%$ sulfuric acid was added into the mixture to stop the reaction. The absorbance was read at $540 \mathrm{~nm}$, and the result was expressed as mg $100 \mathrm{~g}^{-1}$ of fresh weight.

\subsection{Data Analysis}

Statistical analysis was performed using SPSS software (IBM SPPSS Statistic 21, Armonk, NY, USA). The data were analyzed using analysis of variance (ANOVA). Duncan's multiple range test (DMRT) was performed to measure specific differences between means when F-test was significant for bioactive compound analysis. 


\section{Results and Discussion}

\subsection{Proximate Analysis}

Results of the proximate analysis of the fourteen microgreens are shown in Table 3. The total carbohydrate content of the Brassicaceae, black sesame, morning glory, and roselle

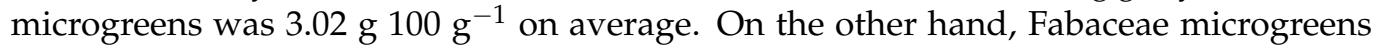
(except green pea) showed a relatively higher carbohydrate content, with mung bean the


known to have a high carbohydrate content of up to $65 \%$ [19].

Table 3. Proximate analysis of the studied microgreens grown under controlled environment.

\begin{tabular}{|c|c|c|c|c|c|c|}
\hline Microgreens & Ash & $\begin{array}{c}\text { Total } \\
\text { Carbohydrate }\end{array}$ & Total Protein & Moisture & Total Fat & Total Calories \\
\hline & \multicolumn{5}{|c|}{$\left(\mathrm{g}_{\left.100 \mathrm{~g}^{-1}\right)}\right.$} & $\left(\mathrm{kcal} 100 \mathrm{~g}^{-1}\right)$ \\
\hline \multicolumn{7}{|c|}{ Brassicaceae } \\
\hline Broccoli & $0.51 \pm 0.02$ & $2.70 \pm 0.20$ & $2.23 \pm 0.11$ & $94.07 \pm 3.11$ & $0.49 \pm 0.01$ & $24.13 \pm 0.20$ \\
\hline Chinese kale & $0.65 \pm 0.00$ & $3.13 \pm 0.11$ & $2.23 \pm 0.00$ & $93.63 \pm 2.12$ & $0.36 \pm 0.02$ & $24.68 \pm 0.22$ \\
\hline Purple radish & $0.52 \pm 0.05$ & $3.70 \pm 0.10$ & $3.41 \pm 0.05$ & $91.88 \pm 1.25$ & $0.49 \pm 0.01$ & $32.85 \pm 0.15$ \\
\hline Radish & $0.44 \pm 0.02$ & $3.29 \pm 0.09$ & $2.58 \pm 0.01$ & $93.19 \pm 1.23$ & $0.50 \pm 0.01$ & $27.98 \pm 0.20$ \\
\hline Rat-tailed radish & $0.43 \pm 0.00$ & $2.91 \pm 0.03$ & $2.50 \pm 0.03$ & $93.50 \pm 2.13$ & $0.66 \pm 0.03$ & $27.58 \pm 0.13$ \\
\hline Red cabbage & $0.75 \pm 0.05$ & $2.32 \pm 0.01$ & $1.88 \pm 0.02$ & $94.67 \pm 3.11$ & $0.38 \pm 0.02$ & $20.22 \pm 0.22$ \\
\hline \multicolumn{7}{|c|}{ Fabaceae } \\
\hline Fenugreek & $0.50 \pm 0.00$ & $5.12 \pm 0.02$ & $4.03 \pm 0.06$ & $90.17 \pm 1.22$ & $0.18 \pm 0.00$ & $38.22 \pm 0.27$ \\
\hline Green pea & $0.36 \pm 0.02$ & $3.39 \pm 0.04$ & $3.73 \pm 0.02$ & $92.37 \pm 2.38$ & $0.15 \pm 0.00$ & $29.83 \pm 0.15$ \\
\hline Lentil & $0.61 \pm 0.00$ & $5.92 \pm 0.01$ & $6.47 \pm 0.11$ & $86.57 \pm 1.12$ & $0.43 \pm 0.02$ & $53.43 \pm 0.19$ \\
\hline Mung bean & $0.64 \pm 0.04$ & $7.16 \pm 0.02$ & $4.55 \pm 0.05$ & $87.29 \pm 2.28$ & $0.36 \pm 0.01$ & $50.08 \pm 0.11$ \\
\hline \multicolumn{7}{|c|}{ Others } \\
\hline Black sesame & $0.34 \pm 0.00$ & $3.58 \pm 0.03$ & $1.92 \pm 0.02$ & $93.75 \pm 2.27$ & $0.41 \pm 0.02$ & $25.69 \pm 0.10$ \\
\hline Buckwheat & $0.34 \pm 0.00$ & $4.90 \pm 0.01$ & $1.75 \pm 0.03$ & $92.74 \pm 1.11$ & $0.27 \pm 0.01$ & $29.03 \pm 0.14$ \\
\hline Morning glory & $0.54 \pm 0.01$ & $3.08 \pm 0.03$ & $1.76 \pm 0.00$ & $94.26 \pm 1.21$ & $0.36 \pm 0.01$ & $22.60 \pm 0.12$ \\
\hline Red roselle & $0.64 \pm 0.00$ & $2.51 \pm 0.05$ & $4.10 \pm 0.07$ & $92.51 \pm 1.19$ & $0.24 \pm 0.01$ & $28.60 \pm 0.07$ \\
\hline
\end{tabular}

Mean $\pm \mathrm{SE}, n=2$.

The total protein content of the studied microgreens ranged from 1.75 and $1.76 \mathrm{~g}$

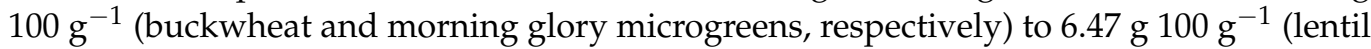
microgreens). Lentils are rich in protein, approximately $16 \%$ albumins, $70 \%$ globulins, $11 \%$ glutelins, and 3\% prolamins, and contain low levels of sulfur-containing amino acids [20,21]. A similar range of protein was found in fenugreek microgreens by Ghoora et al. (2020) [5], but our study obtained a higher protein content in radish and roselle microgreens than the one published.

As expected, the lentil and mung bean microgreens had higher total calories (53.43 and $50.08 \mathrm{~g} 100 \mathrm{~g} \mathrm{~g}^{-1}$, respectively) due to their high carbohydrate and protein contents (Table 3). On the other hand, the other studied microgreens had a relatively low caloric

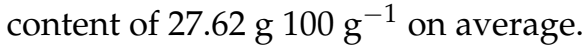

Ash and total fat contents of the microgreens were low. A study on six genotypes of microgreens including Brassica oleracea $\mathrm{L}$. var italica also reported that the lipid content of the microgreens is insignificant [22]. The microgreens contained a high moisture content

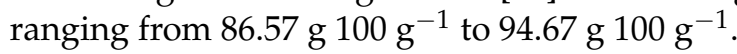

\subsection{Bioactive Compounds}

The coloration of microgreens is one of the main attributes that affect customers' choice of microgreens and their economic value. Chlorophyll and carotenoids are major photosynthetic pigments responsible for the specific coloration of microgreens [23]. These pigments are found to be richer in microgreens than sprouts [24]. In the present study, 
the microgreens showed a total chlorophyll content range of 12.35 to $112.62 \mathrm{mg} 100 \mathrm{~g}^{-1}$. The smallest concentration was found in green pea, while the highest was detected in lentil microgreens. Our results bear a close resemblance to a previous study of radish and fenugreek microgreens [25]. The content of carotenoids had a similar pattern as the content of the total chlorophyll, ranging from 4.40 to $28.37 \mathrm{mg} 100 \mathrm{~g}^{-1}$. Higher carotenoid contents were detected in the Brassicaceae microgreens: broccoli, Chinese kale, radish, and red cabbage, than previously reported $\left(11.9,10.6,11.4\right.$, and $10.4 \mathrm{mg} 100 \mathrm{~g}^{-1}$, respectively)

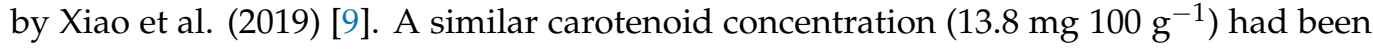
reported for purple radish [9]. Anthocyanin pigments give the attractive red, orange, blue, or purple coloration to plant tissues [26]. Red cabbage and purple radish exhibit purplish-red hypocotyls owing to the accumulation of anthocyanins. The total anthocyanin content detected in red cabbage was higher than purple radish as shown in Table 4 . These pigments not only contribute to the visual quality of microgreens but also their biological activity, making them beneficial to human health $[5,23,27]$.

Table 4. Total chlorophyll, carotenoid, anthocyanin, phenolic, and ascorbic acid contents and total antioxidant activity of the microgreens grown under controlled environment.

\begin{tabular}{|c|c|c|c|c|c|c|c|c|c|c|c|c|}
\hline \multirow{2}{*}{$\begin{array}{l}\text { Common } \\
\text { Name }\end{array}$} & \multicolumn{2}{|c|}{$\begin{array}{l}\text { Total Chlorophyll } \\
\quad\left(\mathrm{mg} 100 \mathrm{~g}^{-1}\right)\end{array}$} & \multicolumn{2}{|c|}{$\begin{array}{l}\text { Carotenoid } \\
\left(\mathrm{mg} 100 \mathrm{~g}^{-1}\right)\end{array}$} & \multicolumn{2}{|c|}{$\begin{array}{c}\text { Anthocyanin } \\
\left(\mathrm{mg} \mathrm{CGE} 100 \mathrm{~g}^{-1}\right)\end{array}$} & \multicolumn{2}{|c|}{$\begin{array}{c}\text { Total Phenolic } \\
\left(\mathrm{mg} \mathrm{GAE} 100 \mathrm{~g}^{-1}\right)\end{array}$} & \multicolumn{2}{|c|}{$\begin{array}{l}\text { Ascorbic Acid } \\
\left(\mathrm{mg} 100 \mathrm{~g}^{-1}\right)\end{array}$} & \multicolumn{2}{|c|}{$\begin{array}{c}\text { DPPH• } \\
\text { Scavenging } \\
\text { Activity } \\
\left(\mathrm{mM} \text { TEAC } \mathrm{g}^{-1}\right)\end{array}$} \\
\hline & 52.26 & $\mathrm{bc}$ & 13.47 & $\mathrm{bc}$ & NA & & 87.56 & cde & 79.11 & a & 35.56 & $\mathrm{~cd}$ \\
\hline $\begin{array}{c}\text { Chinese } \\
\text { kale }\end{array}$ & 58.44 & b & 15.00 & $\mathrm{~b}$ & NA & & 130.59 & $\mathrm{bc}$ & 81.33 & a & 41.90 & c \\
\hline $\begin{array}{l}\text { Purple } \\
\text { radish }\end{array}$ & 49.80 & bcd & 13.12 & bcd & 0.148 & $b$ & 132.78 & $\mathrm{bc}$ & 82.58 & a & 38.50 & g \\
\hline $\begin{array}{c}\text { Radish } \\
\text { Rat- }\end{array}$ & 59.21 & $\mathrm{~b}$ & 15.61 & $\mathrm{~b}$ & NA & & 145.04 & $\mathrm{~b}$ & 56.49 & $\mathrm{~b}$ & 38.39 & $\mathrm{~cd}$ \\
\hline $\begin{array}{l}\text { tailed } \\
\text { radish }\end{array}$ & 36.61 & de & 9.34 & efg & NA & & 143.11 & $\mathrm{~b}$ & 48.24 & $\mathrm{~b}$ & 37.63 & $\mathrm{~cd}$ \\
\hline $\begin{array}{l}\text { Red } \\
\text { cab- } \\
\text { bage }\end{array}$ & 39.79 & cde & 12.08 & bcde & 0.246 & a & 112.29 & bcd & 89.49 & a & 55.45 & $\mathrm{~b}$ \\
\hline Fenugreek & 57.10 & $\mathrm{~b}$ & 14.28 & $\mathrm{~b}$ & NA & & 59.72 & cde & 36.18 & c & 61.48 & $\mathrm{~b}$ \\
\hline $\begin{array}{l}\text { Green } \\
\text { pea }\end{array}$ & 12.35 & $\mathrm{f}$ & 4.40 & $\mathrm{~h}$ & NA & & 38.14 & ef & 42.45 & c & 34.82 & $\mathrm{~cd}$ \\
\hline Lentil & 112.62 & a & 28.37 & a & NA & & 89.05 & bc & 128.70 & a & 36.34 & $\mathrm{~cd}$ \\
\hline $\begin{array}{l}\text { Mung } \\
\text { bean }\end{array}$ & 26.13 & ef & 5.86 & gh & NA & & 59.95 & def & 25.37 & c & 25.50 & e \\
\hline $\begin{array}{c}\text { Black } \\
\text { sesame }\end{array}$ & 37.85 & de & 9.56 & def & NA & & 49.03 & ef & 6.84 & d & 33.44 & de \\
\hline Buckwheat & 34.65 & e & 10.42 & cdef & NA & & 268.99 & a & 62.90 & $\mathrm{~b}$ & 90.83 & a \\
\hline $\begin{array}{l}\text { Morning } \\
\text { glory }\end{array}$ & 28.29 & e & 6.92 & fgh & NA & & 9.22 & $\mathrm{f}$ & 16.78 & $\mathrm{~cd}$ & 10.11 & $\mathrm{f}$ \\
\hline Roselle & 36.37 & de & 8.87 & efg & NA & & 57.06 & ef & 22.23 & $\mathrm{~cd}$ & 42.08 & c \\
\hline
\end{tabular}

Means within columns with the same letter are not significantly different, using DMRT test at $p \leq 0.05$. NA: not available.

The intake of dietary antioxidants is commonly linked with lower risks of certain serious illnesses, including cardiovascular diseases, hypertension, and diabetes [28]. Data from biochemical, clinical, and epidemiological research have recommended a dietary ascorbic acid intake of $90-100 \mathrm{mg}$ day $^{-1}$ to lower the risks of these diseases [25,29]. In the present

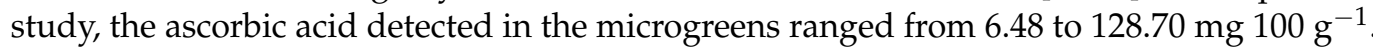
Broccoli, Chinese kale, purple radish, red cabbage, and lentil microgreens exhibited significantly higher ascorbic acid compared to the other microgreens, whereas black sesame microgreens had the least.

Phenolic compounds, products of the phenylpropanoid pathway, are one of the largest secondary metabolites primarily found in fruits and vegetables [30]. These compounds comprise cinnamic acid, benzoic acid, flavonoids, proanthocyanidins, stilbenes, coumarins, lignans and lignin [31]. A significant variation in the total phenolic content of the micro- 
greens was observed, with a range of 9.22 to $268.99 \mathrm{mg}$ GAE $100 \mathrm{~g}^{-1}$. The highest content was found in buckwheat, and the least amount was in morning glory microgreens. The detected values for radish, fenugreek, and roselle microgreens were higher than values reported by Ghoora et al. (2020) [25] but lower than values for broccoli, red cabbage, Chinese kale, radish, and purple radish microgreens reported by another study [9]. These variations could be due to various intrinsic and extrinsic factors, such as species, growth conditions, maturity at harvest, and postharvest conditions [32,33]. The phenolic compounds exhibit direct and indirect antioxidant actions that are beneficial to human health. Their strong antioxidant power lies in their ability to donate electrons to oxidant species, scavenge free radicals, chelate metal ions, and indirectly attenuate the accumulation of reactive oxygen species (ROS) by either improving the activity of antioxidant enzymes or inhibiting enzymes that stimulate pro-oxidant effects [31].

Here, the antioxidant activity of the microgreens was estimated by using DPPH• scavenging activity. Antioxidants in the microgreen extract scavenge the DPPH• through donating a hydrogen atom and converting the radical to a reduced form [25]. The radical scavenging potential is signified by the degree of discoloration of the purple DPPH working solution. Buckwheat microgreens showed remarkably high antioxidant activity compared to others. In contrast, morning glory microgreens registered the lowest $\mathrm{DPPH} \bullet$ scavenging activity. Buckwheat microgreens exhibited about 9-fold higher DPPH• scavenging activity than morning glory microgreens. It should also be noted that buckwheat and morning glory recorded the highest and lowest TPC, respectively. Other studies have also demonstrated a strong positive correlation between TPC and DPPH• scavenging activity $[9,25]$.

\section{Conclusions}

In general, the microgreens investigated in this study were low in calories and fat but high in moisture content. Additionally, the microgreens contained relatively low carbohydrate and protein with the exception of mung beans and lentil microgreens, which had

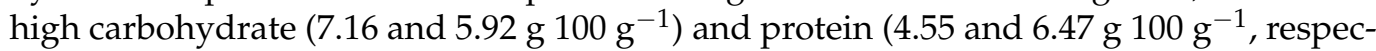
tively) contents. Lentil microgreens had the highest total chlorophyll (112.62 mg $\left.100 \mathrm{~g}^{-1}\right)$, carotenoid (28.37 mg $100 \mathrm{~g}^{-1}$ ), and ascorbic acid (128.70 mg $100 \mathrm{~g}^{-1}$ ) contents. Buckwheat microgreens showed the highest TPC and maximum DPPH• scavenging activity. Only red cabbage and purple radish exhibited anthocyanin content, with the higher content found in red cabbage. The data provided in this study on microgreens of temperate and tropical origins will help farmers to select, expand, and add value to their business with the inclusion of microgreens.

Author Contributions: Conceptualization, V.S. and L.K.; methodology, L.K., N.P., and V.S.; investigation, L.K., V.S., S.P., and P.L.; resources, V.S.; writing—original draft preparation, L.K.; writingreview and editing, V.S. and S.P.; visualization, L.K., S.P., and V.S.; supervision, V.S.; project administration, P.L.; funding acquisition, V.S. All authors have read and agreed to the published version of the manuscript.

Funding: This research was partially funded by Post-Doctoral fellowship from King Mongkut's University of Technology Thonburi, Thailand through Laddawan Kowitcharoen, and National Research Council of Thailand. We also thank the United Graduate School of Agricultural Sciences (UGSAS), Gifu University, Japan, for the research facilities.

Institutional Review Board Statement: Not applicable.

Informed Consent Statement: Not applicable.

Data Availability Statement: Not applicable.

Conflicts of Interest: The authors declare no conflict of interest. 


\section{References}

1. Kyriacou, M.C.; Rouphael, Y.; Gioia, F.D.; Kyratzis, A.; Serio, F.; Renna, M.; Pascale, S.D.; Santamaria, P. Micro-scale vegetable production and the rise of microgreens. Trends Food Sci. Technol. 2016, 57, 103-115. [CrossRef]

2. Di Gioia, F.; Renna, M.; Santamaria, P. Sprouts, microgreens and "baby leaf" vegetables. In Minimally Processed Refrigerated Fruits and Vegetables; Yildiz, F., Wiley, R.C., Eds.; Springer: New York, NY, USA, 2017; pp. 403-428.

3. Kopsell, D.A.; Sams, C.E.; Barickman, T.C.; Morrow, R.C. Sprouting broccoliaccumulate higher concentrations of nutritionally important metab-olites under narrow-band light-emitting diode lighting. J. Am. Soc. Hort. Sci. 2014, 139, 469-477. [CrossRef]

4. Moreira-Rodríguez, M.; Nair, V.; Benavides, J.; Cisneros-Zevallos, L.; Jacobo-Velázquez, D.A. UVA, UVB light, and methyl jasmonate, aloneor combined, redirect the biosynthesis of glucosinolates, phenolics, carotenoids, and chlorophylls in broccoli sprouts. Int. J. Mol. Sci. 2017, 18, 2330. [CrossRef] [PubMed]

5. Ghoora, M.D.; Babu, D.R.; Srividya, N. Nutrient composition, oxalate content and nutritional ranking of ten culinary microgreens. J. Food Compos. Anal. 2020, 91, 103495. [CrossRef]

6. Wojdyło, A.; Nowicka, P.; Tkacz, K.; Turkiewicz, I.P. Sprouts vs. microgreens as novel functional foods: Variation of nutritional and phytochemical profiles and their in vitro bioactive properties. Molecules 2020, 25, 4648. [CrossRef]

7. Márton, M.; Mándoki, Z.; Csapó-Kiss, Z.; Csapó, J. The role of sprouts in human nutrition. A review. Acta Univ. Sapientiae Aliment. 2010, 3, 81-117.

8. Xiao, Z.; Codling, E.E.; Luo, Y.; Nou, X.; Lester, G.E.; Wang, Q. Microgreens of Brassicaceae: Mineral composition and content of 30 varieties. J. Food Compos. Anal. 2016, 49, 87-93. [CrossRef]

9. Xiao, Z.; Rausch, S.R.; Luo, Y.; Sun, J.; Yu, L.; Wang, Q.; Chen, P.; Yu, L.; Stommel, J.R. Microgreens of Brassicaceae: Genetic diversity of phytochemical concentrations and antioxidant capacity. LWT-Food Sci. Technol. 2019, 101, 731-737. [CrossRef]

10. Sangronis, E.; Machado, C.J. Influence of germination on the nutritional quality of Phaseolus vulgaris and Cajanus cajan. LWT-Food Sci. Technol. 2007, 40, 116-120. [CrossRef]

11. Gómez-Maqueo, X.; Soriano, D.; Velázquez-Rosas, N.; Alvarado-López, S.; Jiménez-Durán, K.; Garciadiego, M.M.; Buen, A.G. The seed water content as a timeindependent physiological trait during germination in wild tree species such as Ceiba aesculifolia. Sci. Rep. 2020, 10, 10429. [CrossRef]

12. AOAC. Official Methods of Analysis. 21st Edition, Association of Official Analytical Chemists; AOAC Publishing: Washington, DC, USA, 2019.

13. Moran, R. Formulae for determination of chlorophyllous pigments extracted with $N, N$-dimethylformamide. Plant Physiol. 1982, 69, 1376-1381. [CrossRef]

14. Wellburn, A.R. The Spectral Determination of Chlorophylls a and b, as well as Total Carotenoids, Using Various Solvents with Spectrophotometers of Different Resolution. J. Plant Physiol. 1994, 144, 307-313. [CrossRef]

15. Giusti, M.; Wrolstad, R.E. Characterization and Measurement of Anthocyanins by UV-Visible Spectroscopy. Curr. Protoc. Food Anal. Chem. 2001, 00, F1.2.1-F1.2.13. [CrossRef]

16. Singleton, V.L.; Rossi, J.L. Colorimetry of total phenolics with phosphomolybdic phosphotungstic acid reagents. Am. J. Enol. Vitic. 1965, 16, 144-158.

17. Shimada, K.; Fujikawa, K.; Yahara, K.; Nakamura, T. Antioxidative properties of xanthone on the auto oxidation of soybean in cylcodextrin emulsion. J. Agric. Food Chem. 1992, 40, 945-948. [CrossRef]

18. Roe, J.H.; Mills, M.B.; Oesterling, M.J.; Damron, C.M. The determination of diketo-l-gulonic acid, dehydro-l-ascorbic acid and 1-ascorbic acid in the same tissue extract by the 2,4-dinitrophenylhydrazine method. J. Biol. Chem. 1948, 174, 201-208. [CrossRef]

19. Hedley, C.L. Carbohydrates in Grain Legume Seeds: Improving Nutritional Quality and Agronomic Characteristics; CABI Publishing: New York, NY, USA, 2001.

20. Jarpa-Parra, M. Lentil protein: A review of functional properties and foodapplication. An overview of lentil protein functionality. Int. J. Food Sci. Technol. 2018, 53, 892-903. [CrossRef]

21. Boye, J.; Zare, F.; Pletch, A. Pulse proteins: Praocessing, characterization, functional properties and applications in foodand feed. Food Res. Int. 2010, 43, 414-431. [CrossRef]

22. Paradiso, V.M.; Castellino, M.; Renna, M.; Gattullo, C.E.; Calasso, M.; Terzano, R.; Allegretta, I.; Leoni, B.; Caponio, F.; Santamaria, P. Nutritional characterization and shelf-life of packaged microgreens. Food Funct. 2018, 9, 5629-5640. [CrossRef] [PubMed]

23. Žnidarčič, D.; Ban, D.; Šircelj, H. Carotenoid and chlorophyll composition of commonly consumed leafy vegetables in Mediterranean countries. Food Chem. 2011, 129, 1164-1168. [CrossRef] [PubMed]

24. Fuente, B.; López-García, G.; Máñez, V.; Alegría, A.; Barberá, R.; Cilla, A. Evaluation of the bioaccessibility of antioxidant bioactive compounds and minerals of four genotypes of Brassicaceae microgreens. Foods 2019, 8, 250. [CrossRef] [PubMed]

25. Ghoora, M.D.; Haldipur, A.C.; Srividya, N. Comparative evaluation of phytochemical content, antioxidant capacities and overall antioxidant potential of select culinary microgreens. J. Agric. Food Res. 2020, 2, 100046. [CrossRef]

26. Gonzalez, A.; Zhao, M.; Leavitt, J.; Lloyd, A.M. Regulation of the anthocyanin biosynthetic pathway by the TTG1/bHLH/Myb transcriptional complex in Arabidopsis seedlings. Plant J. 2008, 53, 814-827. [CrossRef] [PubMed]

27. Peng, L.; Zou, L.; Su, Y.; Fan, Y.; Zhao, G. Effects of light on growth, levels of anthocyanin, concentration of metabolites in Fagopyrum tataricum sprout cultures. Int. J. Food Sci. Tech. 2015, 50, 1382-1389. [CrossRef]

28. Prior, R.L.; Cao, G. Antioxidant phytochemicals in fruits and vegetables: Diet and health implications. Hortscience 2000, 35, 588-592. [CrossRef] 
29. Carr, A.C.; Frei, B. Toward a new recommended dietary allowance for vitamin C based on antioxidant and health effects in humans. Am. J. Clin. Nutr. 1999, 69, 1086-1107. [CrossRef]

30. Ho, C.T. Phenolic Compounds in Food: An Overview; ACS Symposium Series; American Chemical Society: Washington, DC, USA, 1992.

31. Hollman, P.C.H. Evidence for health benefits of plant phenols: Local or systemic effects? J. Sci. Food Agric. 2001, 81, 842-852. [CrossRef]

32. Lester, G.E.; Makus, D.J.; Hodges, D.M.; Jifon, J.L. Summer (Subarctic) versus winter (Subtropic) production affects spinach (Spinacia oleracea L.) leaf bionutrients: Vitamins (C, E, Folate, K1, provitamin A), lutein, phenolics, and antioxidants. J. Agric. Food Chem. 2013, 61, 7019-7027. [CrossRef]

33. Stommel, J.R.; Whitaker, B.D.; Haynes, K.G.; Prohens, J. Genotype $\times$ environment interactions in eggplant for fruit phenolic acid content. Euphytica 2015, 205, 823-836. [CrossRef] 